\title{
Inclusive Education: The Forms of Violation of Children's Rights and School Dropouts in the Kadey Division: East Region of Cameroon
}

\author{
Maurice Ndjouma Wedjou
}

ICT University

\begin{abstract}
Article 8 of the African Aspirations for 2063 stipulates that the African people are confident that their countries have the ability and competence to realize or accomplish their full potential in development, culture, and peace. The vast majority of countries in Africa have worked toward establishing flourishing, inclusive, successful and prosperous societies by eradicating any forms of violation of children's rights (African Union Commission, 2015). Nevertheless, violation of children's rights remains present in most developing countries including the country of Cameroon. This research aims to explore the forms of violation of children's rights having a dramatic incident in school attendance in the Kadey Division of Cameroon, East Region of Cameroon. This research work is inductive, values bias and uses the grounded theory of the qualitative method approach. 15 participants have been selected from 3 major focused groups of different stakeholders in the Kadey Division, East Region of Cameroon. The theoretical saturation code was used to explain the relevance of the sample size. Data were examined using the open, axial, and selective coding processes. The results were tested for internal and external validity based on credibility, dependability, conformability, and transferability consideration. The philosophical focused on subjectivism ontology and interpretivism perspective. The study is an investigative case study model. The study showed that the forms of violation of children's rights in the Kadey division include the recruitment and use of children, the denial of humanitarian access, the sexual violence against children and the killing and hurting of children. This study encourages school leaders in the Kadey Division to acknowledge that schools are not meant to function apart from the local community. Promoting strong collaborative work ethics between the major educational stakeholders may help prevent and reduce violence against children within and outside the school milieu and therefore duplicate school attendance. (UNICEF Regional Office for South Asia, 2016).
\end{abstract}

Keywords: Violation of Children's Rights, School Dropout, Kadey Division, Children's Rights

\section{Introduction}

The violation of children's rights is a major concern for many countries around the world and can be seen as a form of privation for children from getting access to the basic living situation. The violations of children's rights are hurtful practices toward a child. (Office of the Special Representative of the Secretary-General for Children and Armed Conflict, 2013). Several rules and laws related to the violation of children's rights have been established by international organizations, and different countries around the world to discourage the expansions of this issue. In the country of Cameroon; laws and regulations which oversee children's rights in term of protection include (i) Law No. 2004/16 of 22 July 2004, on the creation, management, and functioning of "the National Commission on Human Rights and Freedoms" (ii) Law No. 92/04 of 14 April 1992 dealing with school orientation. This law fixes the required "school-going age at 14 years" (iii) "Law No. 67-LF-1 of 12 June 1967 on the penal code and all punishments for violations against children" (iv) "Law No. 2005/015 of 29 December 2005 on combating slavery and child trafficking in Cameroon" (Ekwen, 2015).

Despite this major effort and due to political instability in the South West, North West and Far North of Cameroon; the violation of children's rights remain a reality; since 2016 the civil and social milieu are impacted by violence; affecting negatively the life of Cameroonians in the South and North West Regions. 
The direct consequence of this instability shows that more than 437,000 persons have been forced to move in forests and other localities; the living conditions of children are extremely affected by all those forms of violence surrounding them. (ReliefWeb, 2018).

However and despite the political situation being fairly stable in the rural areas of the Kadey Division in the East Region of Cameroon; the violations of children's rights are very effective and influencing the growth of school dropouts as shown in the graphs below for different school sections.

\section{Graph 1: School Dropout Francophone Section}

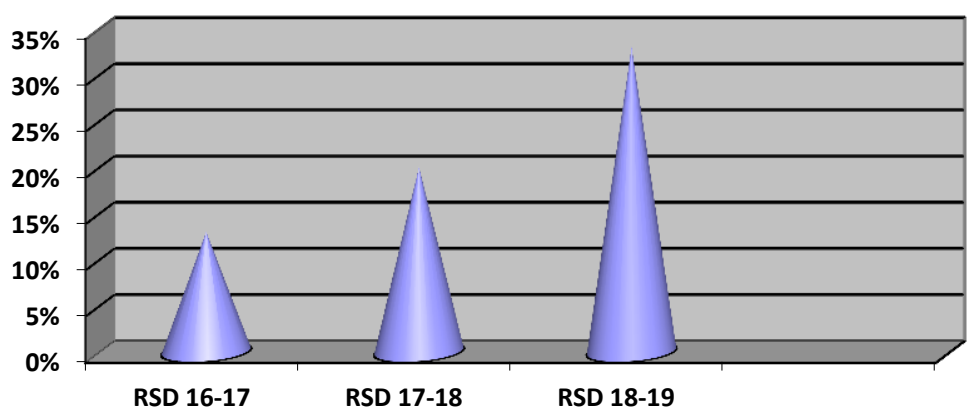

$\square$ School Dropout Francophone Section

Source: Ministry for Secondary Education, East Regional Education: Kadey Division Delegation, Batouri

\section{Graph 2: School Dropout Anglophone Section}

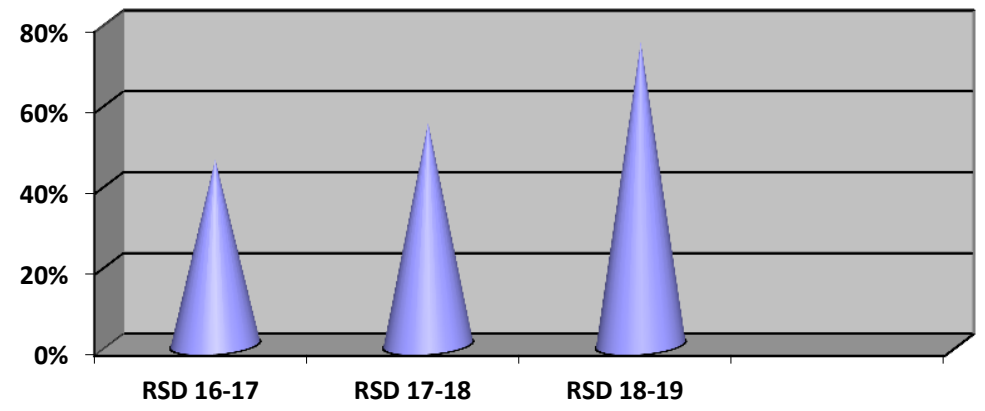

$\square$ School Dropout Anglophone Section

Source: Ministry for Secondary Education, East Regional Education: Kadey Division Delegation, Batouri.

\section{Graph 3: School Dropout Technical Section}

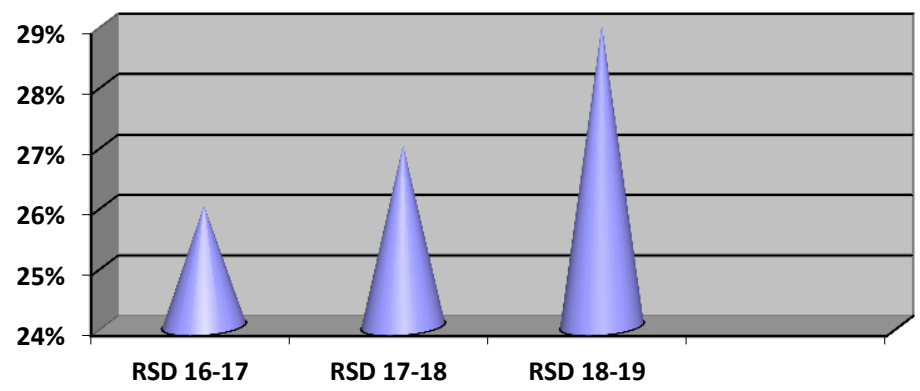

$\square$ School Dropout: Technical Section

Source: Ministry for Secondary Education, East Regional Education: Kadey Division Delegation, Batouri.

RSD 16-17: Rate of School Dropout 2016-2017

RSD 17-18: Rate of School Dropout 2017-2018

RSD 18-19: Rate of School Dropout 2018-2019 


\section{Literature Review}

This study discussed specific concepts including the violation of children's rights and the phenomenon of school dropouts. Education must take place at any time and should not wait for peace to reappear or return. (United Nations, 2011). These two key concepts listed earlier are re-enforced by the humanistic-existential theory and the servant leadership theory as they are relevant and underline the forms of violation of children's rights and its effect in school dropout as emphasized in this research work.

\subsection{Humanistic existential Theory}

This theory develops a strong understanding of the philosophy that is closely linked to the human condition. Humans refer to the statement that students are responsible or accountable. They show self-awareness as well as the strong ability to be potentially self-actualizing (Abiddin N. A., 2012). Students are also able to be entirely functioning and operative. The powers of growth inside each individual are facilitated and simplified via self-disclosure, followed by various steps including the self-acceptance plus the selfawareness (Abiddin N. A., 2012) The humanistic-existential theories focus on some philosophical concepts around the human aspects such as liberty, accountability, and self-actualization. Therefore the educational stakeholders in the Kadey Division must work closely to promote these humans aspects among children to eradicate the violation of children's rights and promote school attendance. The humanistic-existential theories are very important and widely used in the education area as they are expansively applied and utilized in counselling fields (Evans, Forney and Guido-DiBrito, 1998).

\subsection{Servant Leadership Theory}

The Servant Leadership theory states that leaders are the servant. This theory emphasizes on the leaders being available and at the disposition of their followers. This theory was first initiated by Greenleaf in 1970. Servant leaders obtain satisfaction and results by making sure that their follower's needs are reached. Many leadership styles demonstrate how top-level authorities impact and inspire their employees or followers. However; the servant leadership theory puts more importance on collaboration, interaction, trust, sympathy, understanding and moral integrity (Burkus, 2010). These skills are essential and must be exercised by the school leaders in the Kadey Division to effectively tackle the issue of violation of children's rights, which is a major factor of school dropout. A leader must firstly be a servant; leading and guiding people voluntarily to do the best to assist others; instead of trying to get more power. The bottom line is that the servant leader is constantly looking for a way to meet the needs of their followers. Consequently, the followers will then respond positively through improved teamwork, deeper commitment, and outstanding or excellent performance. (Burkus, 2010)

\section{Methodology}

This research work is inductive, values bias and uses the grounded theory of the qualitative method approach. 15 participants have been selected out 3 major focused groups of different stakeholders in the Kadey Division, East Region of Cameroon. Data were examined using the open, axial, and selective coding processes (Glaser \& Strauss, 1967; Corbin, Juliet, \& Strauss, 1990). The results were tested for internal and external validity referring to credibility, dependability, conformability, and transferability considerations (Polit \& Hungler , 1995). The philosophical focused on subjectivism ontology and interpretivism perspective. The study is an investigative case study model (Kothari, 2004; Ming, 2005; Creswell, 2003).

\section{Data Analysis and Presentation of Results}

This grounded theory analysis has three phases including the open coding and theoretical saturation, the axial coding, and the selective coding for the violation of children's rights.

\subsection{Open Coding and Theoretical Saturation for the violation of children's Right}

The first phase of grounded theory analysis is the investigation of thoughts and narratives of participants into codes regarding the violation of children's rights as shown below. 
Table 1: Open Coding and Theoretical Saturation for the Violation of Children's Right

\begin{tabular}{|c|c|c|c|}
\hline FG & Categories & Abbr. & Narratives /codes/ opinions \\
\hline \multirow[t]{5}{*}{ 1: } & Sexual Violence & SEV & $\begin{array}{l}{[\ldots] \text { The Baka girls are constantly being sexually }} \\
\text { abused by their classmates. }\end{array}$ \\
\hline & Denial of Humanitarian & $\mathrm{DEH}$ & $\begin{array}{l}{[\ldots] \text { Many students do not have the birth certificate and }} \\
\text { therefore can participate in official examinations }\end{array}$ \\
\hline & Recruitment of Children & REC & $\begin{array}{l}{[\ldots] \text { Companies promote child labor by hiring minor }} \\
\text { students. }\end{array}$ \\
\hline & $\begin{array}{l}\text { Killing and Hurting of } \\
\text { Children }\end{array}$ & $\mathrm{KHC}$ & [...] Some Parents beat their children for failing grade. \\
\hline & Sexual Violence & SEV & $\begin{array}{l}{[\ldots] \text { Students and most girls are sexually abused or }} \\
\text { harassed by the school staff. }\end{array}$ \\
\hline \multirow[t]{5}{*}{ 2: } & Denial of Humanitarian & $\mathrm{DEH}$ & $\begin{array}{l}{[\ldots] \text { Many villages do not get adequate health treatment }} \\
\text { for lack of hospitals. }\end{array}$ \\
\hline & Recruitment of Children & REC & $\begin{array}{l}{[\ldots] \text { Teachers create big farms and use students as }} \\
\text { laborers. }\end{array}$ \\
\hline & Sexual Violence & SEV & $\begin{array}{l}{[\ldots] \text { Many girls are forced to get married and become }} \\
\text { parents at a younger age. }\end{array}$ \\
\hline & Recruitment of Children & REC & $\begin{array}{l}{[\ldots] \text { Parents force their children to get jobs in the }} \\
\text { mining and tobacco companies to help improve the } \\
\text { family income. }\end{array}$ \\
\hline & $\begin{array}{l}\text { Killing and Hurting of } \\
\text { Children }\end{array}$ & $\mathrm{KHC}$ & $\begin{array}{l}{[\ldots] \text { The Baka students get frequently bullying by other }} \\
\text { students. }\end{array}$ \\
\hline \multirow[t]{5}{*}{3} & Recruitment of Children & REC & $\begin{array}{l}{[\ldots] \text { The Baka students are being employed by the }} \\
\text { Bantu families for housework including farming, } \\
\text { fishing, and hunting. }\end{array}$ \\
\hline & $\begin{array}{l}\text { Killing and Hurting of } \\
\text { Children }\end{array}$ & KHC & [...] Students get whipped constantly by teachers. \\
\hline & Denial of Humanitarian & $\mathrm{DEH}$ & $\begin{array}{l}{[\ldots] \text { The minorities do not receive special protection }} \\
\text { from the local administration when they are being } \\
\text { discriminated against by the Bantu people. }\end{array}$ \\
\hline & Sexual Violence & SEV & $\begin{array}{l}{[\ldots] \text { Very young students are obliged to get involved in }} \\
\text { prostitution or any form of sexual misconduct. }\end{array}$ \\
\hline & $\begin{array}{l}\text { Killing and Hurting of } \\
\text { Children }\end{array}$ & $\mathrm{KHC}$ & $\begin{array}{l}{[\ldots] \text { Few students die by getting involved in traditional }} \\
\text { mining exploitation. }\end{array}$ \\
\hline
\end{tabular}

Source: Field notes (2020)

The table above exhibits four categories of violation of children's rights in the Kadey Division, East region of Cameroon, including the sexual violence against children, denial of humanitarian access, the recruitment and use of children and the killing and hurting of children. These categories are more organized as exposed to the axial coding process below.

\subsection{Axial Coding for the Violation of Children's Right}

The second phase displays the axial coding for the violation of children's right as shown in the table below and followed by the memo. 
Table 2: Axial Coding for the Violation of children's Right

\begin{tabular}{|c|c|c|}
\hline Question & Cat & Narratives / Description / codes \\
\hline \multirow[t]{4}{*}{$\begin{array}{l}\text { Violation of } \\
\text { children's } \\
\text { rights in the } \\
\text { Kadey } \\
\text { Division, } \\
\text { East region } \\
\text { of } \\
\text { Cameroon }\end{array}$} & $\begin{array}{l}\text { Sexual } \\
\text { Violence }\end{array}$ & $\begin{array}{l}{[\ldots] \text { The Baka girls are constantly being sexually abused by their }} \\
\text { classmates. } \\
{[\ldots] \text { Students mostly girls are sexually abused or harassed by the school }} \\
\text { staff. } \\
{[\ldots] \text { Many girls are forced to get married and become parents at a }} \\
\text { younger age. } \\
{[\ldots] \text { Very young students are obliged to get involved in prostitution or }} \\
\text { any form of sexual misconduct. }\end{array}$ \\
\hline & $\begin{array}{l}\text { Denial of } \\
\text { Humanitarian }\end{array}$ & $\begin{array}{l}{[\ldots] \text { Many students do not have the birth certificate and therefore can }} \\
\text { participate in official examinations. } \\
{[\ldots] \text { Many villages do not get adequate health treatment for lack of }} \\
\text { hospitals. } \\
{[\ldots] \text { The minorities do not receive special protection from the local }} \\
\text { administration when they are being discriminated against by the Bantu } \\
\text { people. }\end{array}$ \\
\hline & $\begin{array}{l}\text { Recruitment } \\
\text { of Children }\end{array}$ & $\begin{array}{l}{[\ldots] \text { Companies promote child labor by hiring minor students. }} \\
{[\ldots] \text { Teachers create big farms and use students as laborers. }} \\
{[\ldots] \text { Parents force their children to get jobs in the mining and tobacco }} \\
\text { companies to help improve the family income. } \\
{[\ldots] \text { The Baka students are being employed by the Bantu families for }} \\
\text { housework including farming, fishing, and hunting. }\end{array}$ \\
\hline & $\begin{array}{l}\text { Killing and } \\
\text { Hurting of } \\
\text { Children }\end{array}$ & $\begin{array}{l}{[\ldots] \text { Some Parents beat their children for failing grade. }} \\
{[\ldots] \text { The Baka students get frequently bullying by other students. }} \\
\text { [...] Students get whipped constantly by teachers. } \\
\text { [...] Few students die by getting involved in traditional mining } \\
\text { exploitation. }\end{array}$ \\
\hline
\end{tabular}

Source: Field Data (2020)

Memo:

\section{Sexual Violence against Children}

Several female students including the Baka girls are frequently abused by school staff and classmates. Many of these girls end getting marriage by force or being involved in prostitution and sexual wrongdoings. $11 \%$ of grown-up women were forced to get married, while they were still below the age of 15 and that $48 \%$ of teenage girls aged 15-17 have been the victim of rape and physical abuse many times. (Unicef Cameroon, 2015).

\section{Denial of Humanitarian Access}

The majority of students in the rural areas of the Kadey Division, East Region of Cameroon do not possess a birth registration certificate, and the minorities including the Baka people and the Bororo have no protection from the local administration when persecuted by the Bantu people.

\section{The Recruitment and Use of Children}

Many adults, as well as companies, promote the growth of child labor by recruiting or pushing teenagers to get a job in the mining and tobacco companies. Many Baka children work as a housemaid in the Bantu Families. Some children also hold activities as farmers and hunters. 
Students get whip by teachers and parents and bullying is a constant issue within the school milieu in the Kadey Division. Sometimes it happens that children are engulfed by the earth during traditional gold mine operations.

\subsection{Selective Coding for the Violation of Children's Right}

The third phase represents the selective coding for the Violation of Children's Right with the specific ranking of each factor.

\section{Table 3: Selective Coding for the Violation of children's Right}

\begin{tabular}{|c|c|c|c|}
\hline Question & Categories & Narratives/Description & RK \\
\hline \multirow[t]{4}{*}{$\begin{array}{l}\text { Violation of } \\
\text { children's rights in } \\
\text { the Kadey } \\
\text { Division, East } \\
\text { Region of } \\
\text { Cameroon }\end{array}$} & Sexual Violence & $\begin{array}{l}\text { Students' girls including the Baka people are sexually } \\
\text { abused or harassed by the school staff and classmates; } \\
\text { many girls are forced to get married and become parents } \\
\text { at a younger age; very young students are obliged to get } \\
\text { involved in prostitution or any form sexual misconducts. }\end{array}$ & 4 \\
\hline & $\begin{array}{l}\text { Denial of } \\
\text { Humanitarian }\end{array}$ & $\begin{array}{l}{[\ldots] \text { Many students do not have the birth certificate and }} \\
\text { therefore can participate in official examinations; the } \\
\text { minorities do not receive special protection from the } \\
\text { local administration when they are being discriminated } \\
\text { by the Bantu people. }\end{array}$ & 3 \\
\hline & $\begin{array}{l}\text { The Recruitment } \\
\text { and Use of } \\
\text { Children }\end{array}$ & $\begin{array}{l}\text { [...] Companies and parents promote child labor by } \\
\text { hiring minor students; teachers create big farms and use } \\
\text { students as laborers; the Baka student is being employed } \\
\text { by the Bantu families for housework including farming, } \\
\text { fishing, and hunting. }\end{array}$ & 4 \\
\hline & $\begin{array}{l}\text { The Killing and } \\
\text { Hurting of } \\
\text { Children }\end{array}$ & $\begin{array}{l}\text { [...] Some Parents beat their children for failing grade; } \\
\text { the Baka students get frequently bullying by other } \\
\text { students; students get whipped constantly by teachers; } \\
\text { few students die by getting involved in traditional } \\
\text { mining exploitation. }\end{array}$ & 4 \\
\hline
\end{tabular}

Source: Field Data (2020)

3.4 Modelling of Framework for the Violation of Children's Right, Kadey Division, East Region of Cameroon

Figure 1: Modelling a framework for the violation of children's rights

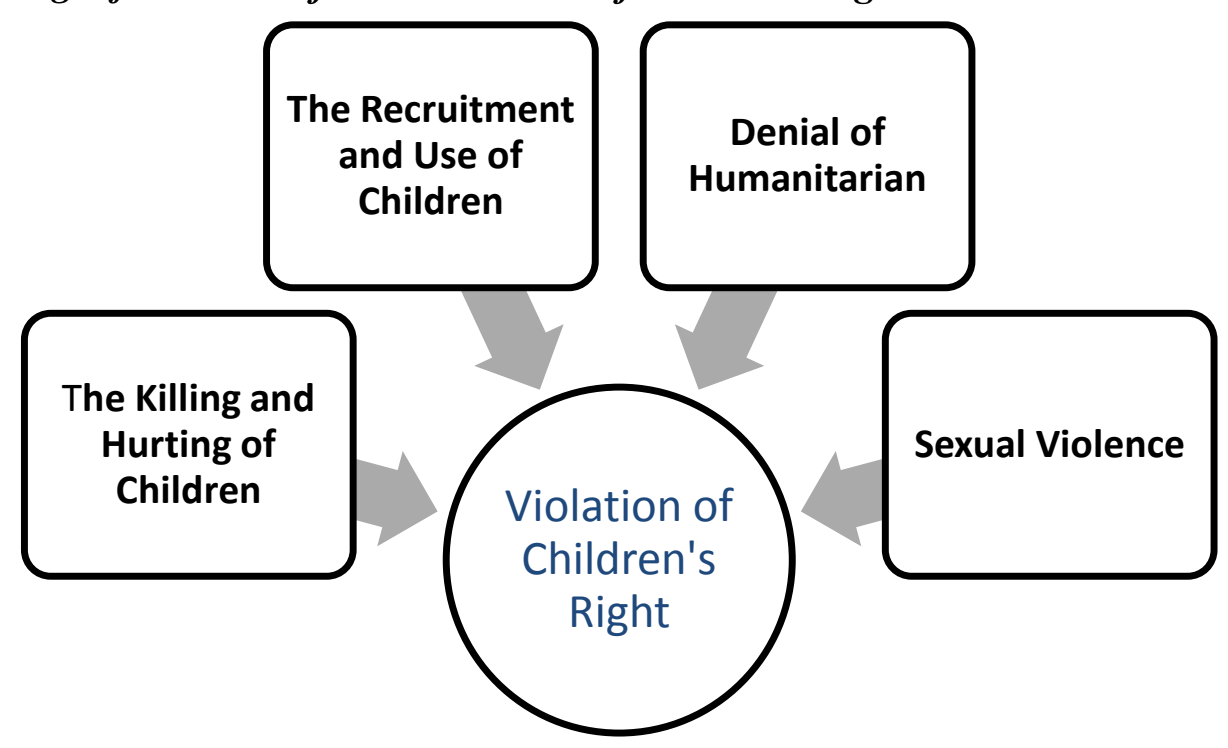


The selective coding table is essential as it displays how much each category is affecting the violation of children's rights in the Kadey Division, East region of Cameroon. The above model demonstrates that violation of children's rights is principally described by the recruitment and use of children, the denial of humanitarian access, the sexual violence against children and the killing and hurting of children.

\section{Discussions and Conclusion}

All these violations of children's rights are seriously affecting girls; the major challenge that the child protection program faces concerns the violence toward the children and mostly girls. Unfortunately; this is common and accepted throughout the Cameroonian community or society. (UNICEF Cameroon Country Programme 2018-2020, 2018). The state of girls' education in the country of Cameroon is disturbing since the majority of girls are facing difficulties having access to the quality of education and most of them are not registered in schools. Referring to the UNESCO Institute Statistics-, 70 percent of girls in Cameroon including those from the Kadey Division of Batouri, East Region of Cameroon are uneducated or illiterate. Most of them are being forced into early marriage. (The Borgen Project, 2018) . According to UNICEF; $30 \%$ of girls are likely to give birth and become a mother before the age of 18 (UNICEF Cameroon Country Programme 2018-2020, 2018).

Working toward eliminating the forms of violations of children's right including the recruitment and use of children, the killing and hurting of children, the denial of humanitarian and the sexual violence in the Kadey Division of Batouri in the East Region of Cameroon would help to make sure that inclusive and impartial equitable education is available for children; which would endorse lifelong opportunity for everyone. (United Nations Department of Public Information, 2015)

\section{Reference}

[1.] Abiddin, N. Z., \& Affero, I. (2012). Exploring Student Development Theory in Enhancing Learning through Supervision. International Journal of Academic Research in Progressive Education and Development, 1(1), 213-217 Unicef Cameroon. (2015). Child Protection in Cameroon.

[2.] African Union Commission. (2015). AFRICAN ASPIRATIONS FOR 2063. Addis Abeba: African Union Commission.

[3.] Burkus, D. (2010, April 1). Servant Leadership Theory.

[4.] Corbin, Juliet, \& Strauss, A. (1990). Grounded Theory Research Approach: Procedure Canons and Evaluative Criteria (Vol. 13).

[5.] Creswell, J. (2003). Research design: qualitative, quantitative, and mixed methods approach (2nd Edition),. Thousand Oaks, CA: Sage Publications.

[6.] Ekwen, L. (2015). Protection of Children's Rights in Cameroon.

[7.] Evans, N. J., Forney, S. D., Guido, M. F., Patton, D., \& Penn, K. A. (2010). Student development in college: Theory, research, and practice (2nd ed.). San Francisco: Jossey-Bass Publishers.

[8.] Glaser, B. G., \& Strauss , A. L. (1967). The Discovery of grounded theory: Strategies for Qualitative Research. Chicago: Aldine Publishing Company.

[9.] Kothari, C. R. (2004.). Research Methodology Methods \& Techniques. New Age International (P) Ltd., Publishers.

[10.] Ming, K. E. (2005.). Research Questions and Research Objectives. The Family Physician.

[11.] Ministry of Education: Kadey Divisional Education. (2019). School Dropout in the Kadey Division. Batouri: Kadey Divisional Education.

[12.] Office of the Special Representative of the Secretary-General for Children and Armed Conflict. (2013, November). The Six Grave Violations Against Children During Armed Conflict: The Legal Foundation.

[13.] Polit, D. F., \& Hungler, B. P. (1995). Nursing Research: Principles and Methods. Philadelphia: JB Lippincott.

[14.] Sheahan, K. (2019). Types of Educational Leadership Theories.

[15.] ReliefWeb. (2018, December 21). Cameroon North West and southwest regions - Child Protection Area of Responsibility.

[16.] United Nations. (2011). The Education for All Agenda. 
[17.] UNICEF Cameroon Country Programme 2018-2020. (2018). Cameroon Child Protection Programme 2018-2020.

[18.] UNICEF Regional Office for South Asia. (2016, April). Violence Against Children in Education Settings in South Asia. 